\title{
Extended nursing and/or increased starter diet allowances for low weaning weight pigs
}

\author{
Aimee-Louise Craig ${ }^{1, *}$, Ramon Muns ${ }^{1, *}$, Alan Gordon ${ }^{2}$, and Elizabeth Magowan ${ }^{1,2}$
}

\author{
* Corresponding Authors: \\ Aimee-Louise Craig \\ Tel: +44-2892682484, Fax: +44-0-28-9025-5035, \\ E-mail: aimee.craig@afbini.gov.uk \\ Ramon Muns \\ Tel: +44-2892682484, Fax: +44-0-28-9025-5035, \\ E-mail: ramon.muns@afbini.gov.uk
}

'Sustainable Agri-Food Sciences Division, Agri-Food and Biosciences Institute, Hillsborough, Northern Ireland BT26 6DR, UK

${ }^{2}$ Sustainable Agri-Food Sciences Division, Agri-Food and Biosciences Institute, Newforge Lane, Belfast, Northern Ireland BT9 5PX, UK

ORCID

Aimee-Louise Craig

https://orcid.org/0000-0002-5142-0836

Ramon Muns

https://orcid.org/0000-0002-8139-8668

Alan Gordon

https://orcid.org/0000-0002-9806-6424

Elizabeth Magowan

https://orcid.org/0000-0001-9038-2310

Submitted Jun 20, 2019; Revised Jul 24, 2019; Accepted Oct 3, 2019
Objective: To evaluate the use of nurse sows and post-weaning nutrition strategies for low wean weight $(\mathrm{WW})$ pigs on lifetime growth and efficiency.

Methods: Animals $(n=270)$ were assigned to one of five treatments at $28 \mathrm{~d}$. Low WW pigs $(<6 \mathrm{~kg})$ were either weaned and offered a special dietary regime recommended for low WW pigs (WEAN) or placed on a nurse sow (NURSE) and weaned at $49 \mathrm{~d}$. Normal WW pigs $(9 \mathrm{~kg})(\mathrm{NORM})$ were also weaned at $28 \mathrm{~d}$. After weaning, NORM and NURSE pigs were offered either a 'high' ( $4 \mathrm{~kg} /$ pig of starter 1 diet followed by $8 \mathrm{~kg} / \mathrm{pig}$ of starter 2 diet) or 'low' ( $8 \mathrm{~kg} /$ pig of starter 2 diet) starter diet allowance in a $2 \times 2$ factorial arrangement. A typical grower diet was then offered, followed by a typical finisher diet until $147 \mathrm{~d}$ of age.

Results: NORM pigs where heavier throughout their life compared to NURSE pigs (91.4 $\mathrm{kg}$ vs $76.2 \mathrm{~kg}$ at $147 \mathrm{~d} ; \mathrm{p}<0.001)$. WEAN pigs were heavier at $70 \mathrm{~d}$ compared to NURSE pigs ( $23.9 \mathrm{~kg}$ vs $21.0 \mathrm{~kg}$; $\mathrm{p}<0.001$ ), but there was no significant difference at $147 \mathrm{~d}$ between NURSE and WEAN treatments. NURSE pigs had reduced feed intake throughout the finishing period $(1.6 \mathrm{~kg} / \mathrm{d} ; \mathrm{p}<0.001)$ compared to WEAN $(2.0 \mathrm{~kg} / \mathrm{d})$ and NORM (1.9 $\mathrm{kg} / \mathrm{d}$ ) pigs. Feed conversion ratio (FCR) of NURSE (2.20) was lower than NORM and WEAN during the finishing period (2.40 and 2.79, respectively).

Conclusion: Extended (up to $49 \mathrm{~d}$ ) nursing for low WW pigs resulted in improved FCR during the finishing period, but no overall improvement in growth rate compared to low WW pigs weaned at $28 \mathrm{~d}$ and offered a specialised starter regime. Normal WW pigs where significantly heavier than low WW pigs throughout the study.

Keywords: Starter Diet; Nurse Sow; Mortality; Light Weight Pigs; Weaning; Growth

\section{INTRODUCTION}

In modern pig production, low weaning weight pigs present a chronic problem due to the use of hyperprolific sows [1]. Low weight pigs at weaning have immature digestive systems, are slower growers, tend to have higher mortality, and poorer carcass value than their heavier counterparts $[2,3]$. There is limited literature on rearing strategies for low weight pigs both pre- and post-weaning [4,5]. Extended suckling has the potential to improve gut maturity at weaning [6], but research on using nurse sows has mainly focused on sow and piglet welfare $[7,8]$ rather than on piglet performance. Increased amounts of starter diets have been found to improve the performance of low weaning weight pigs [9-11]. The present study is the first, known to the authors, investigating the effect of different management systems on life-time performance of low WW pigs ( $<6 \mathrm{~kg}$ at $28 \mathrm{~d}$ ). Therefore, the objective of the study was to evaluate the implementation of nurse sows and different starter diet allowances post-weaning and their impact on the growth of disadvantaged pigs. 


\section{MATERIALS AND METHODS}

The trial was conducted at Agri-Food and Biosciences Institute (AFBI), Hillsborough, Northern Ireland. All experimental procedures were conducted under an experimental licence (no. 2751) granted by the Department of Health, Social Services and Public Safety for Northern Ireland in accordance with the Animals (Scientific Procedures) Act 1986. A total of 270 piglets (PIC 337× [Large White $\times$ Landrace]) from 24 sows were selected at $28 \mathrm{~d}$ of age (end of lactation).

\section{Animals and housing}

At $\mathrm{d} 109$ of gestation, sows were moved to a climate controlled $\left(21.0^{\circ} \mathrm{C}\right)$ farrowing room and allocated to individual farrowing crates $(0.5 \times 2.2 \mathrm{~m})$, each one placed at the centre of a farrowing pen $(2.3 \times 1.5 \mathrm{~m})$. Sows had access to a wet and dry feeder and were fed a commercial lactation diet (13.5 MJ digestible energy (DE) $/ \mathrm{kg}, 94.4 \%$ dry matter, $17 \%$ crude protein $(\mathrm{CP}), 3.6 \%$ crude fibre $(\mathrm{CF})$, and $1 \%$ total Lys). On the farrowing day, sows were offered $2.5 \mathrm{~kg}$ of the lactation diet, and the amount offered increased by $0.5 \mathrm{~kg}$ daily until $10 \mathrm{~kg} / \mathrm{d}$ was reached. The target average feed intake over 28 $\mathrm{d}$ lactation was $8 \mathrm{~kg} / \mathrm{d}$. Attached to the front of each pen, there was a shelter box $(1.5 \times 0.6 \mathrm{~m})$ for piglets equipped with a heated floor pad (heated forward creep area). Temperature in the farrowing rooms and creep areas was electronically controlled. Within 12 hours of birth all piglets had their teeth clipped, tails docked and received $2 \mathrm{~mL}$ of an iron supplement (Uniferon; Virbac Ltd., Suffolk, UK). Piglets were also tagged to allow recording of individual animals. No creep feed was offered to the piglets, and sow troughs were $45 \mathrm{~cm}$ high preventing piglets from easy access to sow feed. At d 28 piglets were vaccinated for M. Hyo and PCV2 with Ingelvac MycoFLEX and Ingelvac CircoFLEX (Boehringer Ingelheim Ld., Bracknell, UK), respectively. Cross-fostering of piglets between litters was performed within the first $24 \mathrm{~h}$ after birth to ensure even litter sizes (av. 12.5 piglets/sow). Piglets were weaned at $28 \pm 2 \mathrm{~d}$ of age.

At weaning, pigs were transferred to nursery accommodation (stage 1 and stage 2 combined) with plastic slatted floors $\left(0.38 \mathrm{~m}^{2} / \mathrm{pig}\right)$. Temperature was $28^{\circ} \mathrm{C}$ on day one and was reduced by $0.5^{\circ} \mathrm{C} / \mathrm{d}$ to a minimum of $18^{\circ} \mathrm{C}$. Pigs were offered feed via a small circular hopper (Rotecna S.A, Agramunt, Spain) for the first week post weaning. Thereafter, pigs were offered feed in a 'dry multi-space feeder' (Etra Feeders Ltd., Dungannon, UK) with a feeder space allowance of 6.6 $\mathrm{cm} /$ pig. At $70 \mathrm{~d}$ of age, pigs were transferred to finishing accommodation with fully slatted concrete floors $\left(0.61 \mathrm{~m}^{2} / \mathrm{pig}\right)$. In the finishing accommodation pigs were offered feed and water via a 'wet and dry' single space shelf feeder (Etra Feeders Ltd., UK) and 1 bowl drinker. One feeder was placed per pen (10 pigs/pen).

\section{Treatments and dietary regime}

A total of 180 low weight pigs $(5.12 \pm 0.780 \mathrm{~kg})$ and 90 normal weight pigs (NORM, $8.92 \pm 0.415 \mathrm{~kg}$ ) were used in the experiment. The trial was carried out over nine time periods or production batches. In each batch, 30 piglets were selected at weaning and allocated to one of the five treatments. Low weight and NORM pigs were distributed to treatments balancing for gender and parity of origin. Low weight pigs were either weaned (WEAN, $\mathrm{n}=90$ ) and offered a special dietary regime recommended for low wean weight pigs $(1 \mathrm{~kg} / \mathrm{pig}$ of special starter diet [18.0 MJ DE/kg, 20.8\% CP, $13.5 \%$ oils and fats, $2.0 \%$ CF, and 1.8\% total Lys; Devenish Nutrition Ltd., Belfast, UK], $4 \mathrm{~kg} /$ pig of starter 1 diet [6.5 MJ DE $/ \mathrm{kg}$, $22.5 \% \mathrm{CP}, 8.5 \%$ oils and fats, $2.5 \% \mathrm{CF}$, and $1.7 \%$ total Lys; Devenish Nutrition Ltd., UK] and $8 \mathrm{~kg} /$ pig of Starter 2 diet [16.0 MJ DE $/ \mathrm{kg}, 22.0 \% \mathrm{CP}, 8.3 \%$ oils and fats, $3.5 \% \mathrm{CF}$, and $1.6 \%$ total Lys; Devenish Nutrition Ltd., UK]) or placed on a nurse sow (NURSE, $n=90$ ) and weaned at $49 \mathrm{~d}$ of age (weaned with the following production batch). No creep feed was offered during the extended suckling period to avoid further confounding of treatment. At weaning, NURSE pigs were offered either 'high' ( $4 \mathrm{~kg} /$ pig of starter 1 diet followed by 8 $\mathrm{kg} /$ pig of starter 2 diet; NURSE 'high', $\mathrm{n}=45$ ) or 'low' ( $8 \mathrm{~kg} / \mathrm{pig}$ of starter 2 diet; NURSE 'low', $\mathrm{n}=45$ ) starter diet allowances. NORM pigs were weaned at $28 \mathrm{~d}$ of age and offered either 'high' ( $\mathrm{n}=45)$ or 'low' $(\mathrm{n}=45)$ starter diet allowances as described above. Sows with a body condition score of at least 2.5 (on a 5 -point scale where: $1=$ very thin to $5=$ overfat) and an average feed intake of $7.5 \mathrm{~kg} / \mathrm{d}$ over a $28 \mathrm{~d}$ lactation, and with a litter size of at least 10 piglets at weaning were selected as nurse sows. Any sow that nursed experimental pigs during the conventional lactation was discarded as a nurse sow.

After pigs had consumed their respective starter allowances (average time: WEAN $4 \mathrm{wk}$, NORM 'high' $3.5 \mathrm{wk}$, NORM 'low' and NURSE 'high' $3 \mathrm{wk}$, NURSE 'low' $2.5 \mathrm{wk}$ ), they were offered ad libitum access to grower diets (13.9 MJ DE/kg, $18.8 \%$ CP, $4.2 \%$ oils and fats, $2.6 \%$ CF, and $1.2 \%$ total Lys) until they reached $84 \mathrm{~d}$ of age. Pigs were then offered a finishing diet (13.4 MJ DE/kg, 17.1\% CP, 3.3\% oils and fats, $3.6 \% \mathrm{CF}$, and $1.0 \%$ total Lys) until the end of the trial (147 $\mathrm{d}$ of age). On transfer to the finishing house, NURSE 'low' and 'high' groups were combined into one pen of 10 pigs and the NORM 'low' and 'high' groups were also combined into one pen of 10 pigs due to housing limitations. Due to the extended lactation, NURSE pigs (both 'high' and 'low') were $21 \mathrm{~d}$ older than their counterparts when transferred to the finishing accommodation and offered the finishing $\operatorname{diet}(105 \mathrm{~d}$ of age instead of $84 \mathrm{~d}$ ).

\section{Measurements}

Pigs were individually weighed and pen feed intakes record- 
ed at weaning ( $28 \mathrm{~d}), 49,70,84,105,126$, and $147 \mathrm{~d}$ of age (irrespective of the treatment). Average daily gain (ADG) was calculated on an individual basis, while average daily feed intake (ADFI) was calculated on a pen basis as: feed consumed divided by the number of pigs per pen. Food conversion ratio (FCR) was also calculated on a pen basis as: food consumed per pen divided by the weight gained within the pen. Mortality was calculated as the percentage of pigs that died or were euthanized in each pen. Blood samples were taken from the jugular vein of a subset of pigs ( $n=10$ /treatment over two time periods) at 1 day pre-weaning (NURSE pigs were $48 \mathrm{~d}$ old, and WEAN and NORM were $27 \mathrm{~d}$ old, respectively), and again at 14 and $28 \mathrm{~d}$ post-weaning (NURSE pigs were $63 \mathrm{~d}$ and $77 \mathrm{~d}$ old and WEAN and NORM pigs were $42 \mathrm{~d}$ and $56 \mathrm{~d}$ old, respectively). Serum was extracted by centrifugation $\left(1509.3 \mathrm{G}\right.$ force for 15 minutes at $18^{\circ} \mathrm{C}$ ) and frozen $\left(-20^{\circ} \mathrm{C}\right)$ until analysis was performed. Analysis was carried out using a commercially available ELIZA Quantitation Set (Cat. No. E100-104, Bethly Laboratories Inc., Montgomery, TX, USA) to test for immunoglobulin G (Ig G) concentration in porcine serum.

\section{Statistical analysis}

Individual pig performance data (body weight, ADG, feed intake, FCR, and mortality) was analysed using the linear mixed model methodology (with pen as the statistical unit) with time period fitted as a random effect using the model: $\mathrm{Y}=\mu+$ sow+diet+sow $\times$ diet+e (sow $=$ NORM, NURSE; diet $=$ high, low). A post-hoc t-test was used to assess the effect of NURSE vs WEAN. Production batch was introduced as fixed effect. Data recorded during the finishing period (feed intake and FCR) was analysed on a pen basis using a one-way analysis of variance with three treatments: WEAN, NURSE, and NORM. No covariates were applied. Serum IgG concentrations were analysed using a general linear model with Treatment introduced as a main effect, and production batch introduced as a fixed effect. IgG concentration at $1 \mathrm{~d}$ preweaning was introduced as a co-variate in the models for IgG concentration at 14 and $28 \mathrm{~d}$ post-weaning. All analyses were carried out using Genstat 16th Edition (Lawes Agriculutral Trust, Rothamsted Experimental Station). Pig growth for each treatment was plotted with a simple linear regression with groups using the model $y(w t)=a x+b$ to predict days to a standard weight of $100 \mathrm{~kg}$.

\section{RESULTS}

\section{Performance from 28 to 70 days of age}

No interactions between NURSE/NORM and high/low dietary regimes were tested between 28 and $49 \mathrm{~d}$ of age because NURSE pigs were still suckling. However, the analysis comparing NORM 'high' and NORM 'low' showed that at $49 \mathrm{~d}$ of age, NORM 'high' was heavier ( $\mathrm{p}<0.001)$ than NORM 'low' $(17.6 \pm 2.29$ vs $14.7 \pm 2.38 \mathrm{~kg})$. In addition, at $49 \mathrm{~d}$ of age the body weight of WEAN $(12.3 \pm 2.47 \mathrm{~kg})$ was higher than NURSE $(10.6 \pm 1.68 \mathrm{~kg})$ and lower than NORM $(16.2 \pm 2.38 \mathrm{~kg})(\mathrm{p}<$ 0.001 , respectively); while body weight of NURSE was lower than NORM $(\mathrm{p}<0.001)$.

The live weight of WEAN pigs was greater at $28 \mathrm{~d}$ and 70 $\mathrm{d}$ of age than the NURSE pigs (Table $1 ; \mathrm{p}<0.001$ ). ADG from 49 to $70 \mathrm{~d}$ of age was also greater for WEAN pigs than NURSE pigs $(\mathrm{p}<0.05)$. NORM pigs were on average $8 \mathrm{~kg}$ heavier than NURSE pigs $(\mathrm{p}<0.001)$ at $70 \mathrm{~d}$ of age. Pigs on the 'high' starter diet allowance were heavier $(\mathrm{p}<0.001)$ and had greater ADG from 49 to $70 \mathrm{~d}$ of age $(\mathrm{p}<0.001)$ than those on the 'low' starter diet allowance.

From 49 to $70 \mathrm{~d}$ of age WEAN pigs ate more than NURSE pigs (Table 2; $\mathrm{p}<0.001$ ). Pigs on the 'high' starter allocation ate more than those on the 'low' allocation from 49 to $70 \mathrm{~d}$ of age $(\mathrm{p}<0.05)$. NORM pigs also ate more than the NURSE pigs ( $p<0.001$ ) between 49 to $70 \mathrm{~d}$ of age. Pen FCR from 49 to $70 \mathrm{~d}$ of age (Table 2 ) was improved when NURSE pigs were offered the 'low' starter diet allowance, but not when NORM pigs were offered the 'low' starter diet allowance $(\mathrm{p}<0.05)$. WEAN pigs had increased FCR from 49 to $70 \mathrm{~d}$ of age compared to NURSE pigs ( 1.80 vs $1.16 ; \mathrm{p}<0.001$ ). From 49 to 70 $\mathrm{d}$ of age, pigs offered the 'high' starter allowance had increased FCR compared to pigs offered 'low' starter allowance (1.42 vs $1.40 ; \mathrm{p}<0.05)$. Also from 49 to $70 \mathrm{~d}$ of age, NURSE pigs had lower FCR than NORM pigs (1.16 vs 1.67 ; $\mathrm{p}<0.001$ ).

\section{Performance from 70 to 147 days of age}

There were no interactive effects between treatments on live weight and ADG in the finishing stage (Table 1). Live weights and ADG for NORM pigs were consistently higher than NURSE and WEAN pigs. WEAN pigs were heavier than NURSE pigs at $84 \mathrm{~d}$ of age $(\mathrm{p}<0.001)$, but not at 105,126 , or $147 \mathrm{~d}$ of age. ADG of WEAN and NURSE pigs did not differ between 84 to $147 \mathrm{~d}$ of age ( $\mathrm{p}>0.05$ ). Pigs that had 'high' starter diet allocations were consistently heavier throughout the finishing period $(\mathrm{p}<0.001)$ and had greater ADG from 84 to $147 \mathrm{~d}$ of age $(\mathrm{p}<0.05)$ than those offered the 'low' allocation of starter diets.

No differences were found in ADFI between treatments from 70 to $126 \mathrm{~d}$ of age ( $\mathrm{p}>0.05$, Table 3). From 126 to $147 \mathrm{~d}$ of age, NURSE pigs consumed less than the other treatments $(\mathrm{p}<0.001)$. NURSE pigs had a lower overall intake from 70 to $147 \mathrm{~d}$ of age than NORM and WEAN treatments $(\mathrm{p}<0.001)$. Throughout the finishing period, NURSE pigs had a consistently lower FCR than WEAN pigs $(\mathrm{p}<0.001)$ except from 70 to $84 \mathrm{~d}$ of age (p>0.05). From 70 to $147 \mathrm{~d}$ of age NURSE pigs had lower FCR than both WEAN and NORM pigs ( $\mathrm{p}<$ 0.001). 
Table 1. Effect of treatment on piglet lifetime live weight and weight gain

\begin{tabular}{|c|c|c|c|c|c|c|c|c|c|c|}
\hline \multirow[b]{2}{*}{ Items } & \multirow[b]{2}{*}{ WEAN $^{1)}$} & \multicolumn{2}{|c|}{ NURSE $^{2)}$} & \multicolumn{2}{|c|}{ NORM $^{3)}$} & \multirow[b]{2}{*}{ SED } & \multicolumn{4}{|c|}{$\mathrm{p}$-values } \\
\hline & & $\mathrm{High}^{4)}$ & Low $^{5)}$ & High & Low & & $\begin{array}{c}\text { WEAN vs } \\
\text { NURSE }\end{array}$ & High vs low & $\begin{array}{c}\text { NURSE vs } \\
\text { NORM }\end{array}$ & Interactions ${ }^{6)}$ \\
\hline$n^{\circ}$ of pigs $/ n^{\circ}$ of pens ${ }^{7)}$ & $90 / 9$ & $45 / 9$ & $45 / 9$ & $45 / 9$ & $45 / 9$ & & & & & \\
\hline \multicolumn{11}{|l|}{ Live weight (kg) } \\
\hline $28 \mathrm{~d}$ of age & 5.5 & 5.1 & 4.8 & 8.9 & 8.9 & 0.1 & $<0.001$ & 0.198 & $<0.001$ & 0.147 \\
\hline $49 \mathrm{~d}$ of $\mathrm{age}^{8)}$ & 12.3 & 10.8 & 10.4 & 17.6 & 14.7 & - & - & - & - & - \\
\hline $70 \mathrm{~d}$ of age & 23.9 & 22.2 & 19.8 & 31.6 & 27.3 & 0.8 & $<0.001$ & $<0.001$ & $<0.001$ & 0.116 \\
\hline $84 \mathrm{~d}$ of age & 33.8 & 32.3 & 29.2 & 42.9 & 36.9 & 1.2 & $<0.001$ & $<0.001$ & $<0.001$ & 0.277 \\
\hline $105 \mathrm{~d}$ of age & 45.2 & 49.1 & 44.6 & 56.7 & 50.1 & 1.7 & 0.208 & $<0.001$ & $<0.001$ & 0.404 \\
\hline $126 \mathrm{~d}$ of age & 59.3 & 63.2 & 58.4 & 72.3 & 65.1 & 2.3 & 0.369 & $<0.001$ & $<0.001$ & 0.484 \\
\hline $147 \mathrm{~d}$ of age & 79.9 & 78.5 & 73.9 & 96.0 & 86.8 & 2.8 & 0.084 & $<0.001$ & $<0.001$ & 0.274 \\
\hline \multicolumn{11}{|l|}{ Average daily gain $(\mathrm{g} / \mathrm{d})$} \\
\hline 49 to $70 \mathrm{~d}$ of age & 551 & 542 & 450 & 669 & 597 & 28 & 0.009 & $<0.001$ & $<0.001$ & 0.634 \\
\hline 70 to $84 \mathrm{~d}$ of age & 712 & 723 & 668 & 772 & 686 & 39 & 0.560 & 0.015 & 0.289 & 0.595 \\
\hline 84 to $105 \mathrm{~d}$ of age & 548 & 798 & 732 & 684 & 630 & 40 & $<0.001$ & 0.045 & $<0.001$ & 0.842 \\
\hline 105 to $126 \mathrm{~d}$ of age & 693 & 676 & 651 & 757 & 716 & 48 & 0.409 & 0.357 & 0.050 & 0.836 \\
\hline 126 to $147 \mathrm{~d}$ of age & 990 & 721 & 740 & 1,102 & 1,029 & 54 & $<0.001$ & 0.459 & $<0.001$ & 0.251 \\
\hline 84 to $147 \mathrm{~d}$ of age & 743 & 734 & 701 & 834 & 773 & 30 & 0.280 & 0.034 & $<0.001$ & 0.539 \\
\hline
\end{tabular}

SED, standard error of difference.

1) WEAN = low weight pigs $(5.1 \pm 0.78 \mathrm{~kg})$ weaned at $28 \mathrm{~d}$ of age and offered $1 \mathrm{~kg} / \mathrm{pig}$ of special starter diet, $4 \mathrm{~kg} / \mathrm{pig}$ of starter 1 diet, and $8 \mathrm{~kg} / \mathrm{pig}$ of starter 2 diet.

2) NURSE, low weight pigs $(5.1 \pm 0.78 \mathrm{~kg})$ placed on a nurse sow and weaned at $49 \mathrm{~d}$ of age.

${ }^{3)}$ NORM, normal weight pigs $(8.9 \pm 0.41 \mathrm{~kg})$ weaned at $28 \mathrm{~d}$ of age.

4) High, pigs offered $4 \mathrm{~kg} / \mathrm{pig}$ of starter 1 diet followed by $8 \mathrm{~kg} / \mathrm{pig}$ of starter 2 diet at weaning.

5) Low, pigs offered $8 \mathrm{~kg} / \mathrm{pig}$ of starter 2 diet at weaning.

${ }^{6)}$ Interaction between starter diet allowance (high/low) and type of pig (NURSE/NORM).

7) From d 70 to 147, NURSE and NORM groups were combined into 10 pig pens.

${ }^{8)}$ No statistical analysis as NURSE pigs had not been offered high or low starter treatments.

\section{Prediction of growth to $100 \mathrm{~kg}$}

The plotted linear regression indicated that the growth curves for each treatment were distinct $\left(\mathrm{p}<0.001 ; \mathrm{R}^{2}=0.89\right)$. The equations for each treatment are as follows (liveweight, LWT;
SE, standard error):

NORM high:

LWT $=-7.872($ SE 1.050) $+0.6408($ SE 0.010622$) \times$ day

Table 2. Effect of treatment on feed intake and feed conversion ratio of nursery pigs

\begin{tabular}{|c|c|c|c|c|c|c|c|c|c|c|}
\hline \multirow[b]{2}{*}{ Items } & \multirow[b]{2}{*}{ WEAN $^{1)}$} & \multicolumn{2}{|c|}{ NURSE $^{2)}$} & \multicolumn{2}{|c|}{ NORM $^{3)}$} & \multirow[b]{2}{*}{ SED } & \multicolumn{4}{|c|}{$p$-values } \\
\hline & & $\operatorname{High}^{4)}$ & Low $^{5)}$ & High & Low & & $\begin{array}{c}\text { WEAN vs } \\
\text { NURSE }\end{array}$ & High vs low & $\begin{array}{c}\text { NURSE vS } \\
\text { NORM }\end{array}$ & Interactions $^{6)}$ \\
\hline 49 to $70 \mathrm{~d}$ of age & 987 & 678 & 599 & 1,138 & 985 & 47.9 & $<0.001$ & 0.002 & $<0.001$ & 0.281 \\
\hline FCR & & & & & & & & & & \\
\hline 28 to $70 \mathrm{~d}$ of age & 1.3 & 4.2 & 7.1 & 0.0 & 0.0 & 1.38 & $<0.001$ & 0.158 & $<0.001$ & 0.148 \\
\hline 70 to $147 \mathrm{~d}$ of age & 10.7 & 2.2 & 6.7 & 7.8 & 0.0 & 4.53 & 0.117 & 0.606 & 0.863 & 0.064 \\
\hline 28 to $147 \mathrm{~d}$ of age & 12.1 & 6.7 & 15.6 & 7.8 & 0.0 & 5.17 & 0.935 & 0.763 & 0.040 & 0.040 \\
\hline
\end{tabular}

SED, standard error of difference; $A D F I$, average daily feed intake; $F C R$, food conversion ratio.

1) WEAN, low weight pigs $(5.1 \pm 0.78 \mathrm{~kg}$ ) weaned at $28 \mathrm{~d}$ of age and offered $1 \mathrm{~kg} / \mathrm{pig}$ of special starter diet, $4 \mathrm{~kg} / \mathrm{pig}$ of starter 1 diet, and $8 \mathrm{~kg} / \mathrm{pig}$ of starter 2 diet.

2) NURSE, low weight pigs $(5.1 \pm 0.78 \mathrm{~kg})$ placed on a nurse sow and weaned at $49 \mathrm{~d}$ of age.

3) NORM, normal weight pigs $(8.9 \pm 0.41 \mathrm{~kg})$ weaned at $28 \mathrm{~d}$ of age.

4) High, pigs offered $4 \mathrm{~kg} /$ pig of starter 1 diet followed by $8 \mathrm{~kg} / \mathrm{pig}$ of starter 2 diet at weaning.

5) Low, pigs offered $8 \mathrm{~kg} / \mathrm{pig}$ of starter 2 diet at weaning.

${ }^{6)}$ Interaction between starter diet allowance (high/low) and type of pig (NURSE/NORM).

${ }^{7)}$ From d 70 to 147, NURSE and NORM groups were combined into 10 pig pens. 
Table 3. Effect of treatment on finishing pig performance

\begin{tabular}{|c|c|c|c|c|c|}
\hline Items & WEAN $^{1)}$ & NURSE $^{2)}$ & NORM $^{3)}$ & SED & $\mathrm{p}$-value \\
\hline$n^{\circ}$ of pigs $/ n^{\circ}$ of pens & $90 / 9$ & $85 / 9$ & $90 / 9$ & & \\
\hline \multicolumn{6}{|l|}{ ADFI (g/d) } \\
\hline 70 to $84 \mathrm{~d}$ of age & 1,394 & 1,210 & 1,322 & 54.4 & 0.086 \\
\hline 84 to $105 \mathrm{~d}$ of age & 1,528 & 1,459 & 1,567 & 55.5 & 0.404 \\
\hline 105 to $126 \mathrm{~d}$ of age & 1,936 & 1,552 & 1,874 & 109.0 & 0.052 \\
\hline 126 to $147 \mathrm{~d}$ of age & $2,948^{b}$ & $1,978^{\mathrm{a}}$ & $2,694^{b}$ & 102.2 & $<0.001$ \\
\hline 70 to $147 \mathrm{~d}$ of age & $1,988^{b}$ & $1,579^{\mathrm{a}}$ & $1,904^{b}$ & 44.6 & $<0.001$ \\
\hline \multicolumn{6}{|l|}{ FCR } \\
\hline 70 to $84 \mathrm{~d}$ of age & 2.11 & 1.73 & 1.90 & 0.151 & 0.241 \\
\hline 84 to $105 \mathrm{~d}$ of age & $2.87^{\mathrm{c}}$ & $1.91^{\mathrm{a}}$ & $2.49^{\mathrm{b}}$ & 0.125 & $<0.001$ \\
\hline 105 to $126 \mathrm{~d}$ of age & $2.95^{b}$ & $2.37^{\mathrm{a}}$ & $2.63^{\mathrm{a}}$ & 0.100 & 0.003 \\
\hline 126 to $147 \mathrm{~d}$ of age & $3.08^{b}$ & $2.70^{\mathrm{a}}$ & $2.53^{\mathrm{a}}$ & 0.077 & $<0.001$ \\
\hline 70 to $147 \mathrm{~d}$ of age & $2.79^{c}$ & $2.20^{\mathrm{a}}$ & $2.40^{\mathrm{b}}$ & 0.062 & $<0.001$ \\
\hline
\end{tabular}

SED, standard error of difference; $A D F I$, average daily feed intake; $F C R$, food conversion ratio.

1) WEAN, low weight pigs $(5.1 \pm 0.78 \mathrm{~kg})$ weaned at $28 \mathrm{~d}$ of age.

2) NURSE, low weight pigs $(5.1 \pm 0.78 \mathrm{~kg})$ placed on a nurse sow and weaned at $49 \mathrm{~d}$ of age.

${ }^{3)}$ NORM, normal weight pigs $(8.9 \pm 0.41 \mathrm{~kg})$ weaned at $28 \mathrm{~d}$ of age.

a-c Means within a row with different superscripts differ $(p<0.05)$.

NORM low:

$\mathrm{LWT}=-7.597($ SE 1.029) $+0.5796($ SE 0.010188$) \times$ day

NURSE high:

LWT $=-9.131($ SE 1.042)+0.5522 (SE 0.010514) $\times$ day

NURSE low:

$\mathrm{LWT}=-8.547($ SE 1.084) $+0.5115($ SE 0.011129$) \times$ day

WEAN:

LWT $=-8.242($ SE 0.811) $+0.5381($ SE 0.007399) $\times$ day

Using these equations, time to $100 \mathrm{~kg}$ was $169 \mathrm{~d}, 186 \mathrm{~d}$, 198 d, 212 d, and $201 \mathrm{~d}$ for NORM high, NORM low, NURSE high, NURSE low, and WEAN, respectively (Figure 1).

\section{Mortality and serum IgG concentrations}

Pig mortality between 28 to $70 \mathrm{~d}$ of age was higher in NURSE pigs than WEAN pigs (Table 2; $\mathrm{p}=0.001$ ) and was $0 \%$ for NORM pigs. There was no significant effect of starter diet allowance on pig mortality during from 28 to $70 \mathrm{~d}$ of age. From 70 to $147 \mathrm{~d}$ of age there was no significant difference between treatments. There was an interaction between the lifetime mortality of NURSE and NORM pigs on the 'high' and 'low' starter diets $(\mathrm{p}<0.05)$. NORM pigs had higher mortality on the 'high' starter diet allocation than on the 'low', whereas NURSE pigs had lower mortality on the 'high' starter diet allocation than on the 'low' ( $\mathrm{p}<0.05$, respectively).

Figure 2 shows the serum IgG concentration for each treatment group. At $1 \mathrm{~d}$ pre-weaning NURSE 'high' had higher IgG concentration than the other treatment groups $(\mathrm{p}<0.05$, respectively), NURSE 'low' was higher than NORM 'high'
( $\mathrm{p}<0.05)$. At $14 \mathrm{~d}$ post-weaning, NURSE 'low' and 'high' had both higher IgG concentration than NORM 'high' ( $\mathrm{p}<0.05$, respectively). At $28 \mathrm{~d}$ post-weaning WEAN and NORM 'high' had both lower IgG concentration than NORM 'low' ( $\mathrm{p}<0.05$, respectively), and lower than NURSE 'high' and NURSE 'low' $(\mathrm{p}<0.001$, respectively).

\section{DISCUSSION}

On commercial farms pigs are being weaned as light as $3 \mathrm{~kg}$ at $28 \mathrm{~d}$ and a wean weight of $7.5 \mathrm{~kg}$ is a common average wean weight at $28 \mathrm{~d}$ of age [12]. To better investigate the performance of disadvantaged pigs ( $5.12 \pm 0.780 \mathrm{~kg}$ of body weight) through to the end of the finishing period (147 d of age), NORM pigs $(8.9 \pm 0.41 \mathrm{~kg})$ were included in the study to set a standard against which any improvements could be compared.

At weaning, the resultant weight of pigs on the WEAN treatment was higher than those on the NURSE 'low' treatment. Initially, low weight pig treatments (WEAN, NURSE 'high' and 'low') were analysed separately from the NORM treatments and weaning weight was introduced as covariate in the models to correct for the initial difference. The growth pattern and treatment differences observed were the same as with the inclusion of NORM pigs in the analysis. Therefore, although the initial difference in weaning weight has been considered in the discussion, it was not considered to invalidate the interpretation of the statistic outcome. It is also recognised that combining both NURSE treatments into one pen, and both NORM treatments into one pen at the start of the finishing period, may have potential for bias in terms of feed intake and FCR. Therefore, the effect of 'high' and 'low' starter 


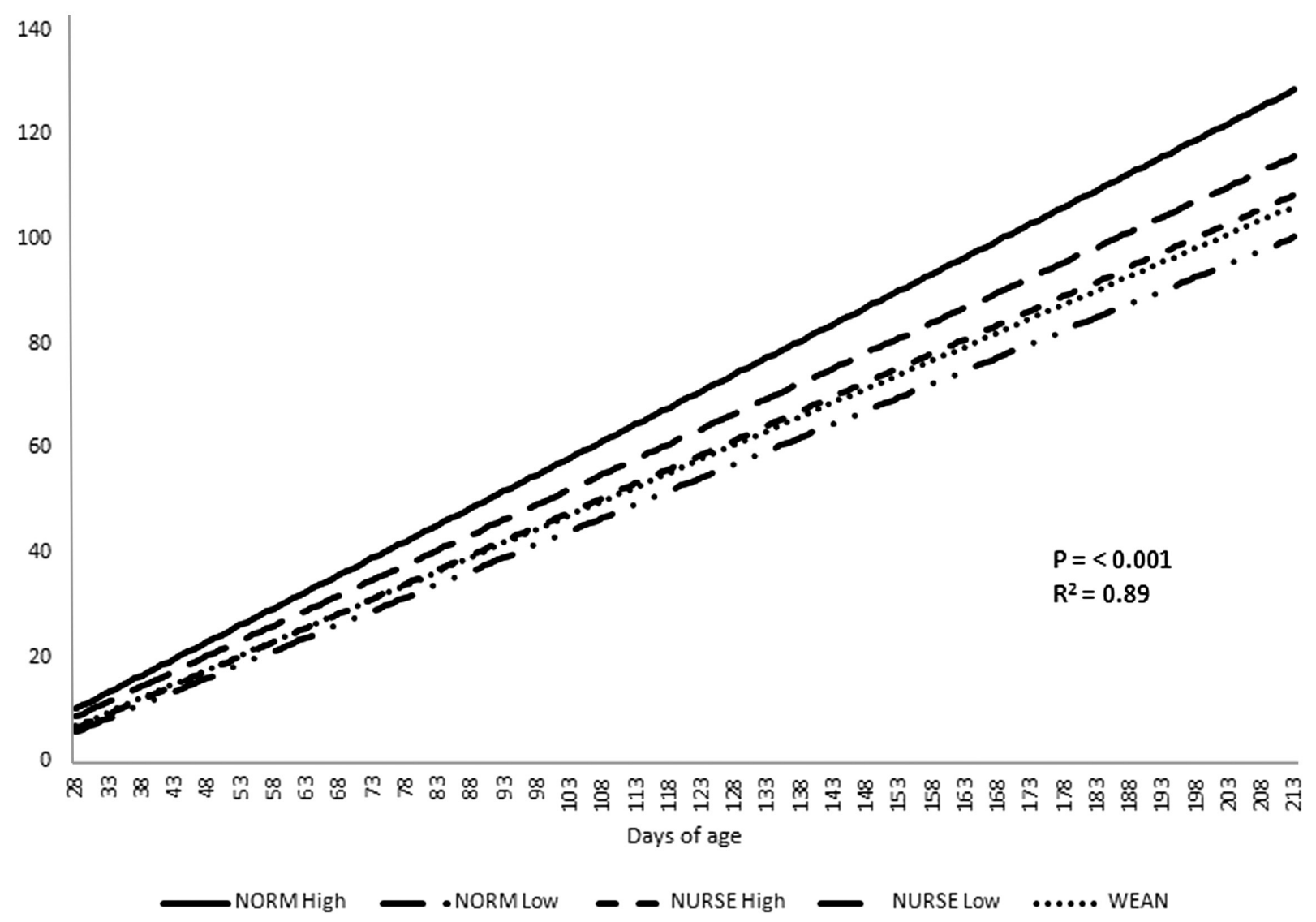

Figure 1. Predicted days to $100 \mathrm{~kg}$ liveweight. NORM high, normal weight pigs $(8.9 \pm 0.41 \mathrm{~kg})$ weaned at $28 \mathrm{~d}$ of age, then offered $4 \mathrm{~kg} / \mathrm{pig}$ of starter 1 diet followed by 8 $\mathrm{kg} / \mathrm{pig}$ of starter 2 diet at weaning; NORM low, normal weight pigs $(8.9 \pm 0.41 \mathrm{~kg})$ weaned at $28 \mathrm{~d}$ of age, then offered $8 \mathrm{~kg} /$ pig of Starter 2 diet at weaning; NURSE high, low weight pigs $(5.1 \pm 0.78 \mathrm{~kg})$ placed on a nurse sow and weaned at $49 \mathrm{~d}$ of age, then offered $4 \mathrm{~kg} / \mathrm{pig}$ of Starter 1 diet followed by $8 \mathrm{~kg} / \mathrm{pig}$ of starter 2 diet at weaning; NURSE low, low weight pigs $(5.1 \pm 0.78 \mathrm{~kg})$ placed on a nurse sow and weaned at $49 \mathrm{~d}$ of age, then offered $8 \mathrm{~kg} /$ pig of starter 2 diet at weaning; WEAN, low weight pigs $(5.1 \pm 0.78 \mathrm{~kg})$ weaned at $28 \mathrm{~d}$ of age and offered $1 \mathrm{~kg} / \mathrm{pig}$ of special starter diet, $4 \mathrm{~kg} / \mathrm{pig}$ of starter 1 diet, and $8 \mathrm{~kg} / \mathrm{pig}$ of starter 2 diet.

diet on the finishing period have not been discussed. Nonetheless, the results are considered relevant to the scientific and commercial audience and the work has been completed to ensure treatments were properly compared.

\section{Impact on growth performance}

At $70 \mathrm{~d}$ of age, pigs on the WEAN treatment had a $12.7 \%$ weight advantage compared to NURSE pigs ( 23.9 vs $21.0 \mathrm{~kg}$ ). However, NURSE pigs were still suckling during the first half of this period, with no access to creep feed, while WEAN pigs were being offered solid diets (more nutrient dense than milk). Therefore, it would be recommended to offer creep feed to piglets suckling nurse sows to enhance their feed intake post-weaning and subsequent growth $[9,11]$.

In the WEAN treatment, pig ADG was reduced by $164 \mathrm{~g} / \mathrm{d}$ between 84 to $105 \mathrm{~d}$ of age which coincided with the change from grower to finisher diet. This suggests that these pigs, weighing $34 \mathrm{~kg}$ on average, were not ready for the finisher diet. Previous research [13] also found that a similar finisher diet (18.6 MJ gross energy, $0.8 \mathrm{~g} / \mathrm{kg}$ available lysine) was inadequate for pigs less than $40 \mathrm{~kg}$. However, in treatments
NORM (45 kg) and NURSE (40 kg) ADG was also reduced by $72 \mathrm{~g} / \mathrm{d}$ and $102 \mathrm{~g} / \mathrm{d}$ in the $21 \mathrm{~d}$ period after the finisher diet was introduced. This suggests that even pigs of $40 \mathrm{~kg}$ where not ready for the finisher diet. It has been suggested previously that it is economically viable to offer a grower diet up to $60 \mathrm{~kg}$ of live weight to optimise performance [14]. Indeed evidence from this trial suggests that introducing the finisher diet based on live weight (perhaps up to $60 \mathrm{~kg}$ ) would be more beneficial than based on age.

As expected, the live weight of the NORM pigs was greater than the low weight pig treatments throughout the growing and finishing periods. Weaning weight plays a critical role in growth [15] and has been suggested as a better predictor of future growth than birth weight [16].

\section{Feed conversion ratio and feed intake}

The NURSE piglets had improved FCR compared to both the NORM and WEAN pigs throughout their post-weaning life. This may be explained by the fact NURSE pigs had lower intake (average of $1.6 \mathrm{~kg} / \mathrm{d}$ ) from 70 to $147 \mathrm{~d}$ of age compared to WEAN and NORM groups (overall av. of $1.9 \mathrm{~kg} / \mathrm{d}$ ). NURSE 


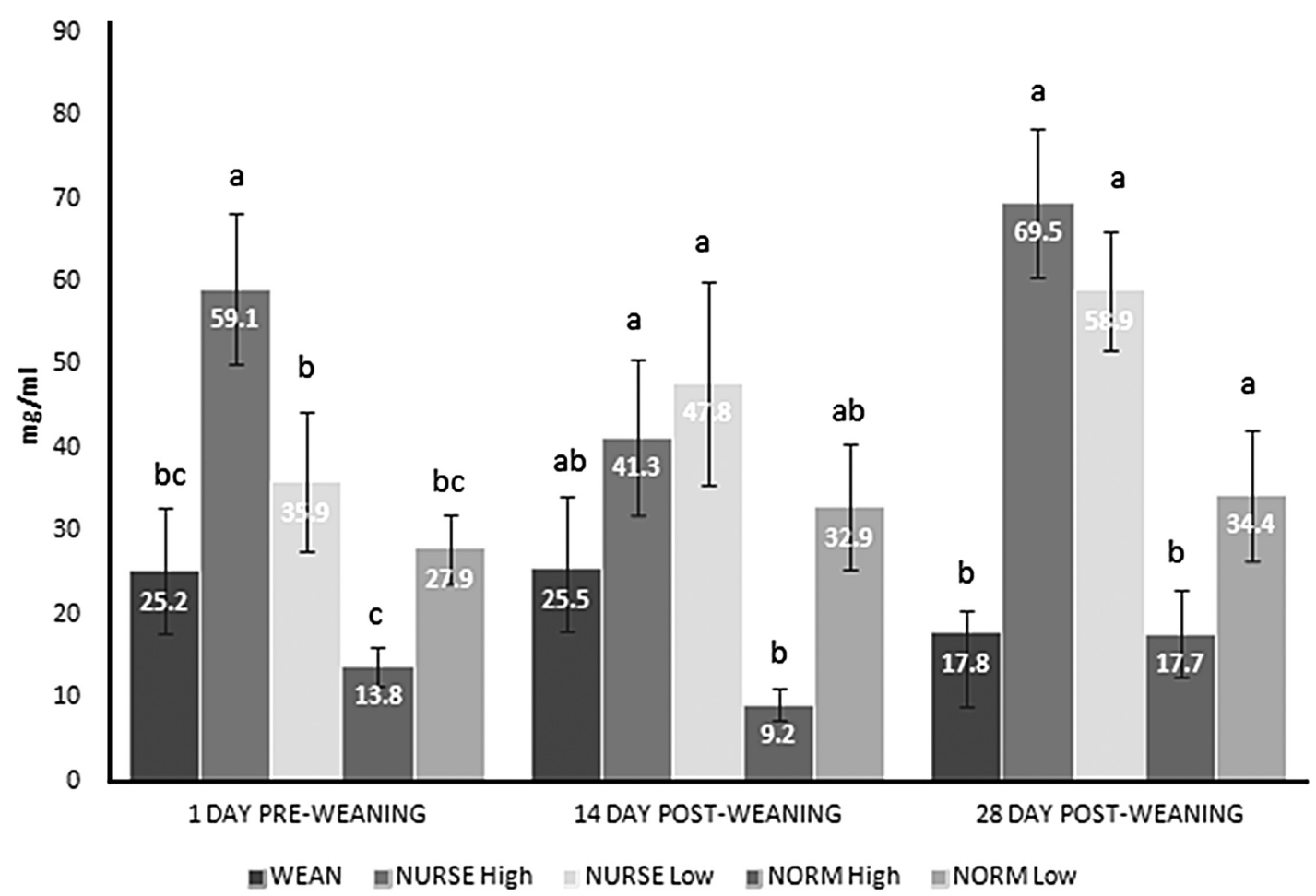

Figure 2. Serum immunoglobulin $\mathrm{G}(\mathrm{lg} \mathrm{G})$ concentrations across treatments. WEAN, low weight pigs $(5.1 \pm 0.78 \mathrm{~kg})$ weaned at $28 \mathrm{~d}$ of age and offered $1 \mathrm{~kg} / \mathrm{pig}$ of special starter diet, $4 \mathrm{~kg} / \mathrm{pig}$ of starter 1 diet, and $8 \mathrm{~kg} / \mathrm{pig}$ of starter 2 diet; NORM high, normal weight pigs $(8.9 \pm 0.41 \mathrm{~kg})$ weaned at $28 \mathrm{~d}$ of age, then offered $4 \mathrm{~kg} / \mathrm{pig}$ of starter 1 diet followed by $8 \mathrm{~kg} / \mathrm{pig}$ of starter 2 diet at weaning; NORM low, normal weight pigs $(8.9 \pm 0.41 \mathrm{~kg})$ weaned at $28 \mathrm{~d}$ of age, then offered $8 \mathrm{~kg} / \mathrm{pig}$ of Starter 2 diet at weaning; NURSE high, low weight pigs $(5.1 \pm 0.78 \mathrm{~kg})$ placed on a nurse sow and weaned at $49 \mathrm{~d}$ of age, then offered $4 \mathrm{~kg} / \mathrm{pig}$ of starter 1 diet followed by $8 \mathrm{~kg} / \mathrm{pig}$ of starter 2 diet at weaning; NURSE low, low weight pigs $(5.1 \pm 0.78 \mathrm{~kg}$ ) placed on a nurse sow and weaned at $49 \mathrm{~d}$ of age, then offered $8 \mathrm{~kg} / \mathrm{pig}$ of starter $2 \mathrm{diet}$ at weaning.

a-c Bars with different superscripts differ $(p<0.05)$.

pigs were offered higher specification diets for their age due to older weaning age. It is known that diets with higher nutrient densities improve FCR [17]. When NORM and NURSE treatments were both offered the finisher diet at the same time (from 105 to $147 \mathrm{~d}$ of age), FCR did not differ statistically. It is also possible that the extended suckling period may have improved gut function [6] and contributed to the reduced post-weaning growth check.

In other studies, offering a high allowance of starter diet improved pig growth, especially for low wean weight pigs $[10,11,18]$. However, in contrast to these studies there was no increase in feed intake to compensate for low nutrient specification in the low allowance in this study. It could be because the difference between high and low allocations were more severe and therefore less palatable for piglets offered the Starter 2 diet immediately post-weaning. The rationale behind this design was that the older piglets coming off a nurse sow at $49 \mathrm{~d}$ may have been able to tolerate the lower specification Starter 2 diet. Indeed, the difference in performance between the high and low treatments in NURSE pigs was less, although not significant, than the high and low treatments for NORM pigs both at $70 \mathrm{~d}(2.4 \mathrm{~kg}$ vs $4.4 \mathrm{~kg})$ and $147 \mathrm{~d}$ weeks (4.6 kg vs $9.2 \mathrm{~kg}$ ); therefore if NORM weight pigs had been
NURSE treated their growth and efficiency could be hypothesised to be greater. It has been noted historically that suckling pigs of normal weight, when offered an ad libitum milk diet can reach ADG of over $0.5 \mathrm{~kg} / \mathrm{d}$ [19]. With modern genetics, NORM pigs should have even greater growth potential than has been realised, but their growth quickly outstrips the sow's milk yield.

\section{Mortality and serum IgG concentrations}

NURSE treatments had greater mortality in the nursery period (up to $70 \mathrm{~d}$ of age) than in the finishing period. However, for WEAN and NORM 'high' treatments there was very little mortality in the nursery, while over $7.5 \%$ of pigs died in the finishing house. Poor thrift was the main cause of death, although all pigs were vaccinated for PCV 2. The pattern of mortality had an impact on economics. Economically, the NORM treatments had the highest margin over feed cost. This is expected as $8.9 \mathrm{~kg}$ pigs at $28 \mathrm{~d}$ are likely to achieve better $147 \mathrm{~d}$ weights and be more efficient than small pigs [15]. Despite the added cost of feeding a sow for $21 \mathrm{~d}$, feed costs for NURSE treatment was lower than for WEAN pigs (per 10 pigs). WEAN pigs had higher mortality later in the finishing house, which likely contributed to their lower economic val- 
ue as the expensive starter diets had been eaten by pigs who did not reach slaughter. Calculating the age at which the treatments would reach a target of $100 \mathrm{~kg}$ live weight from their individual treatment growth curves, NURSE High would have finished $3 \mathrm{~d}$ before WEAN pigs, but $14 \mathrm{~d}$ quicker than NURSE low. In comparison, NORM high and low pigs would have finished 29 and $12 \mathrm{~d}$ before NURSE high. Therefore, from an economic perspective and also from a pig throughput perspective, light weaning weight pigs allowed to suckle a sow for a further $21 \mathrm{~d}$, and then offered a High allocation of starter diets perform better than pigs weaned and offered a three starter diet regime.

As expected, NURSE pigs (both 'high' and 'low') had higher concentrations of serum IgG than the other groups in the 3 measuring points, indicating improved humoral immunity [20], mainly due to being of older age at each measuring point. Surprisingly, NORM 'high' pigs had significantly lower IgG concentration than NORM 'low' at $28 \mathrm{~d}$ post-weaning, and did not differ from WEAN pigs at any sampling point. In contrast, a different study [21] found lower IgG concentration in low $(\approx 5 \mathrm{~kg})$ wean weight pigs compared to normal ( $\approx 7 \mathrm{~kg}$ ) wean weight pigs. Our findings might suggest that, at the same age, small pigs might benefit from a higher quality diet post-weaning, whereas in normal weight pigs a 'high' starter diet allowance does not enhance their immunological maturity compared to a 'low' allowance. More research is needed to understand the impact of starter diet and its allowance on piglets' active immune capacity based on their weaning weight.

\section{CONCLUSION}

A weight difference of $3.8 \mathrm{~kg}$ at weaning increased to $7.4 \mathrm{~kg}$ and $13.8 \mathrm{~kg}$ at 70 and $147 \mathrm{~d}$ respectively between the NORM $(8.9 \pm 0.41 \mathrm{~kg})$ and light weight pigs $(5.1 \pm 0.78 \mathrm{~kg})$. Low weight pigs allowed to suckle a nurse sow until $49 \mathrm{~d}$ of age and then offered 'high' allowance of starter diet and a later transition to the finisher diets (105 d of age), had similar weight at 147 $\mathrm{d}$ of age but an improved finisher FCR (2.20 vs 2.79 ) compared to low weight pigs weaned at $28 \mathrm{~d}$ and offered a high specification dietary regime. The present study has identified the opportunity to improve the lifetime FCR of low weaning weight pigs by extending the lactation period using nurse sows. Nonetheless, further research is needed to better understand the implications for mortality and to identify the most efficient post-weaning feeding strategy.

\section{CONFLICT OF INTEREST}

We certify that there is no conflict of interest with any financial organization regarding the material discussed in the manuscript.

\section{ACKNOWLEDGMENTS}

This work was part of a PhD project sponsored by DARD and Pig Regen Ltd. The authors gratefully acknowledge the funders and the technical and farm staff at AFBI Hillsborough.

\section{REFERENCES}

1. Quiniou N, Dagorn J, Gaudre D. Variation of piglets' birth weight and consequences on subsequent performance. Livest Prod Sci 2002;78:63-70. https://doi.org/10.1016/S0301-6226 (02)00181-1

2. Cole DJA, Close WH. The modern pig setting performance targets. Anim Talk 2001;8:3.

3. Michiels J, De Vos M, Missotten J, et al. Maturation of digestive function is retarded and plasma antioxidant capacity lowered in fully weaned low birth weight piglets. Br J Nutr 2013;109:65-75. https://doi.org/10.1017/S0007114512000670

4. Muns R, Nuntapaitoon M, Tummaruk P. Non-infectious causes of pre-weaning mortality in piglets. Livest Sci 2016;184:4657. https://doi.org/10.1016/j.livsci.2015.11.025

5. Solà-Oriol D, Gasa J. Feeding strategies in pig production: sows and their piglets. Anim Feed Sci Technol 2017;233:3452. https://doi.org/10.1016/j.anifeedsci.2016.07.018

6. Berkeveld M, Langendijk P, Soede NM, et al. Improving adaptation to weaning: effect of intermittent suckling regimens on piglet feed intake, growth, and gut characteristics. J Anim Sci 2009;87:3156-66. https://doi.org/10.2527/jas.2008-1764

7. Baxter EM, Rutherford KMD, D'Eath RB, et al. The welfare implications of large litter size in the domestic pig II: management factors. Anim Welf 2013;22:219-38. https://doi.org/10. 7120/09627286.22.2.219

8. Sørensen JT, Rousing T, Kudahl AB, Hansted HJ, Pedersen LJ. Do nurse sows and foster litters have impaired animal welfare? Results from a cross-sectional study in sow herds. Animal 2016;10:681-6. https://doi.org/10.1017/S175173111 5002104

9. Lawlor PG, Lynch PB, Caffrey PJ, O’ Doherty JV. Effect of pre- and post-weaning management on subsequent pig performance to slaughter and carcass quality. Anim Sci 2002;75: 245-56. https://doi.org/10.1017/S1357729800053005

10. Magowan E, Ball MEE, McCracken KJ, et al. The performance response of pigs of different wean weights to 'high' or 'low' input dietary regimes between weaning and 20 weeks of age. Livest Sci 2011;136:232-9. https://doi.org/10.1016/j.livsci.2010. 09.010

11. Muns R, Magowan E. The effect of creep feed intake and starter diet allowance on piglets' gut structure and growth performance after weaning. J Anim Sci 2018;96:3815-23. https:// doi.org/10.1093/jas/sky239

12. Calderón Díaz JA, Boyle LA, Diana A, et al. Early life indicators predict mortality, illness, reduced welfare and carcass char- 
acteristics in finisher pigs. Prev Vet Med 2017;146:94-102. https://doi.org/10.1016/j.prevetmed.2017.07.018

13. Ball MEE, Magowan E, McCracken KJ, et al. The effect of level of crude protein and available lysine on finishing pig performance, nitrogen balance and nutrient digestibility. AsianAustralas J Anim Sci 2013;26:564-72. https://doi.org/10.5713/ ajas.2012.12177

14. Beattie VE, Lawrence EMK, Marshall B, et al. Feeding the finishing pig. Proceedings of 'Research to drive sustainable production' 2015 November 10th; Hillsborough, Northern Ireland, UK.

15.Douglas SL, Edwards SA, Sutcliffe E, Knap PW, Kyriazakis I. Identification of risk factors associated with poor lifetime growth performance in pigs. J Anim Sci 2013;91:4123-32. https://doi.org/10.2527/jas.2012-5915

16.Smith AL, Stalder KJ, Serenius TV, Baas TJ, Mabry JW. Effect of piglet birth weight on weights at weaning and 42 days post weaning. J Swine Health Prod 2007;15:213-8.

17. Apple JK, Maxwell CV, Brown DC, et al. Effects of dietary lysine and energy density on performance and carcass char- acteristics of finishing pigs fed ractopamine. J Anim Sci 2004; 82:3277-87. https://doi.org/10.2527/2004.82113277x

18. Douglas SL, Wellock I, Edwards SA, Kyriazakis I. High specification starter diets improve the performance of low birth weight pigs to 10 weeks of age. J Anim Sci 2014;92:4741-50. https://doi.org/10.2527/jas.2014-7625

19. Hodge RMW. Efficiency of food conversion and body composition of the pre-ruminant lamb and the young pig. Br J Nutr 1974;32:113-26. https://doi.org/10.1079/BJN19740062

20.Lauridsen C. Evaluation of the effect of increasing dietary vitamin $\mathrm{E}$ in combination with different fat sources on performance, humoral immune responses and antioxidant status of weaned pigs. Anim Feed Sci Technol 2010;158:85-94. https:// doi.org/10.1016/j.anifeedsci.2010.03.015

21. Hernandez A, Hansen CF, Mansfield J, Mullan BP, Pluske JR. The responses of light- and heavy-for-age pigs at weaning to dietary spray-dried porcine plasma. Anim Feed Sci Technol 2010;162:116-22. https://doi.org/10.1016/j.anifeedsci.2010. 08.016 